\title{
CHUK wt Allele
}

National Cancer Institute

\section{Source}

National Cancer Institute. CHUK wt Allele. NCI Thesaurus. Code C52510.

Human CHUK wild-type allele is located within 10q24-q25 and is approximately $80 \mathrm{~kb}$ in length. This allele, which encodes inhibitor of nuclear factor kappa-B kinase subunit alpha protein, is involved in the progression of nuclear factor kappa B complex signaling. 